\title{
FREQUENCY OF SPONDYLOLYSIS AND CHRONIC LOW BACK PAIN IN YOUNG SOCCER PLAYERS
}

\author{
FREQUÊNCIA DE ESPONDILÓLISE E LOMBALGIA CRÔNICA EM JOVENS JOGADORES DE FUTEBOL
} FRECUENCIA DE ESPONDILOLISIS Y DOLOR LUMBAR CRÓNICA EN JÓVENES FUTBOLISTAS

Marcos Vaz de Lima ${ }^{1}$, Aires Duarte Júnior ${ }^{1}$, Pedro Baches Jorge ${ }^{1}$, Flavio Fernandes Bryk ${ }^{1}$, Robert Meves ${ }^{1}$, Osmar Avanzi ${ }^{1}$

\begin{abstract}
Objective: To demonstrate the safety of soccer for adolescents in terms of chronic lesions of the lumbar spine, particularly spondylolysis. Methods: 54 young players underwent a pre-season assessment. The athletes were submitted to radiography of the lumbosacral spine. Players complaining of chronic low back pain were later submitted to more specific tests. Results: only 1 athlete (1.85 \% of our sample) had complaints of chronic low back pain. In this case, the radiograph showed olisthesis grade I spondylolysis at the L5 level. Conclusion: Soccer proved to be a very safe sport in terms of the risk of developing chronic lesions of the lumbosacral spine. However, the actual incidence of spondylolysis in these athletes was not determined because only plain radiographs were used in this study.
\end{abstract}

Keywords: Low back pain; Athletes; Soccer; Spondylolysis.

\begin{abstract}
RESUMO
Objetivo: Demonstrar a segurança da prática do futebol para adolescentes em relação às lesões crônicas da coluna lombar, em especial a espondilólise. Métodos: Cinquenta e quatro jovens jogadores realizaram a avaliação da pré-temporada. Os atletas foram submetidos a radiografias da coluna lombossacra. Jogadores com queixa de lombalgia crônica seriam submetidos posteriormente a exames mais específicos. Resultados: Apenas um atleta tinha queixa de lombalgia crônica. Neste caso, a radiografia evidenciou espondilólise bilateral de L5 com listese grau I (1,85\% de nossa casuística). Conclusão: O futebol de campo mostrou ser um esporte bastante seguro quanto ao risco de desenvolvimento de lesões crônicas da coluna lombossacra. No entanto a real incidência da espondilólise nesses atletas não foi determinada, porque apenas radiografias simples foram utilizadas neste estudo.
\end{abstract}

Descritores: Lombalgia; Atleta; Futebol; Espondilólise.

\section{RESUMEN}

Objetivo: Demostrar la seguridad de la práctica de fútbol para los adolescentes en relación con las lesiones lumbares crónicas, especialmente espondilólisis. Métodos: Cincuenta y cuatro jóvenes jugadores realizaron la evaluación de la pretemporada. Los atletas fueron sometidos a una radiografía de la columna lumbosacra. Los jugadores con queja de dolor lumbar crónico se presentarían posteriormente a pruebas más específicas. Resultados: Sólo un atleta tenía quejas de dolor lumbar crónico. En este caso, la radiografía mostró espondilólisis bilateral de L5 con olistesis de grado I (1,85 \% de la muestra). Conclusión: El fútbol resultó ser un deporte muy seguro para el riesgo de aparición de lesiones crónicas de la columna lumbosacra. Sin embargo, la incidencia real de espondilólisis en estos atletas no se determinó debido a que sólo las radiografías simples se utilizaron en este estudio.

Descriptores: Dolor de espalda baja; Atletas; Fútbol; Espondilólisis.

\section{INTRODUCTION}

Among the spinal injuries in athletes, disorders of the lumbar region are the most common. Depending upon the type of sport, the prevalence of chronic low back pain can reach as high as $86 \%{ }^{1-3}$ The association between the practice of sports and the development of spinal injuries is established in the literature, particularly in impact sports and those requiring repetitive flexion-extension movements, rotation, and axial load. ${ }^{2-4}$ Weightlifters, boxers, golfers, gymnasts, and dancers are the athletes most affected by these clinical and radiographic changes. ${ }^{1,2,4}$ In addition to the type of sport, the incidence of low back pain in athletes depends on other factors such as intensity, frequency, and training technique, among others. ${ }^{4,5}$ In most cases, it presents in an acute and self-limiting form, caused mainly by injuries to the ligaments and paraspinal muscles. The persistence of symptoms in young athletes may suggest other diagnostic hypotheses, especially spondylolysis ${ }^{5-8}$ and degenerative disc disease..$^{2-4}$
Spondylolysis is a bone defect of the posterior neural arch and in $95 \%$ of cases it affects the pars interarticularis of L5.5,6,9 Its physiopathology has not been explained in detail, but the hypothesis that it is a stress fracture caused by excessive load is widely accepted. . 10,11 Anatomical and biomechanical changes to the positioning of the sacrum in relation to the ground, the degree of lordosis, occult spina bifida, and family history are other possible factors in the development of this change. , $9,12,13$ Its prevalence in the general population is between 3\% and $5 \%$ and in young athletes it can reach as high as $60 \%$, depending on the sport involved. ${ }^{6,14}$ Participants in impact sports or in sports with repetitive movements with mechanical-type low back pain (related to movement) that worsens with the extension and shortening of the ischiotibial muscles raise a clinical suspicion that can be confirmed through complementary exams: simple radiographies, computed tomography (CT), total body bone scintigraphy, mag-

1. Faculdade de Ciências Médicas da Santa Casa de São Paulo, São Paulo, SP, Brazil.

Study conducted at the Department of Orthopedics andTraumatology of the Irmandade da Santa Casa de Misericórdia de São Paulo - Pavilhão Fernandinho Simonsen, São Paulo, SP, Brazil.

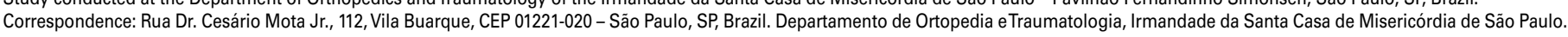
marcos.lima@fcmsantacasasp.edu.br 
netic resonance imaging (MRI), and more recently, single-photon emission computed tomography (SPECT), ${ }^{10,15}$ for some authors the gold standard for diagnosis ${ }^{10}$ but still little used in our country. Radiculopathy is a rare symptom, but possible, due to the proximity of the nerve root to the inflammatory process. ${ }^{11}$

Isthmic spondylolisthesis, according to the classification of Wiltse et $\mathrm{al}^{16}$, is the presence of spondylolysis combined with the separation of the neural arch from the vertebral body following its anterior dislocation, and in athletes, this association is present in $30 \%$ of cases, although there is rarely any effective progression of this slippage..$^{17}$

On the other hand, there is no scientific evidence that playing soccer increases the chances of developing low back pain of any etiology. ${ }^{18,19}$ The loads and the exhaustively repeated sports moves indicated as risk factors for the development of spondylolysis in sports where there has been a proven increased incidence are apparently not performed as often in soccer.

The objective of this study is to demonstrate the safety of playing soccer for adolescents as regards chronic injuries of the lumbar spine, especially spondylolysis.

\section{MATERIALS AND METHODS}

We conducted a prospective study in which 54 players from a soccer school were evaluated during the 2010 pre-season at the Sports Trauma Clinic of the Santa Casa de São Paulo. The complete evaluation included a general orthopedic evaluation, and a specific evaluation of the spine. The players' legal guardians signed consent forms, and the project was approved by the Research Ethics Committee (REC) of the institution. The criteria for inclusion in the group were ages between 8 and 12 years, no presentation of other orthopedic injuries, and participation in a minimum of $90 \%$ of the training sessions. All the athletes were male, and trained at the same field, an average of three times a week for four hours each session, as well as playing in weekend games, managed by the same coach and physical trainer

Simple anterior-posterior and profile radiographies were taken of the athletes' lumbosacral spines. Players who reported chronic low back pain subsequently underwent computed tomography, bone scintigraphy, and magnetic resonance imaging.

\section{RESULTS}

The average age was 11.47 years, ranging from 8 to 12 years. Only one athlete complained of chronic low back pain of the mechanical type (related to strain), without sciatica, that worsened with extension and shortening of the ischiotibial muscles, but he was able to participate in the training sessions normally. The radiography showed bilateral spondylolysis of L5 with grade I lysthesis. (Figure 1) Computed tomography, full body bone scintigraphy, and magnetic resonance imaging were performed for verification and documentation. (Figures 2, 3, and 4) This case corresponded to $1.85 \%$ of our case series.

None of the other athletes had any complaints of low back pain or changes in the anterior-posterior or profile radiographies.

\section{DISCUSSION}

Brazil is world-renowned as the country of soccer, a sport which is mainly played by young males. ${ }^{19}$ Professionalization of the sport has led to an increasingly earlier start of intense training for the competitive level, leaving aside the recreational and educational goals of this activity. Along with this increase in training loads, severe injuries, especially chronic injuries, have become more common in children and adolescents. Our study was conducted at the traditional Escola de Futebol do Clube Pequeninos do Jockey soccer school, to evaluate the pre-season training for the participation of the athletes in several championships, the main highlight being two international tournaments in Norway, in which they were the distinguished champions this year, 2010.

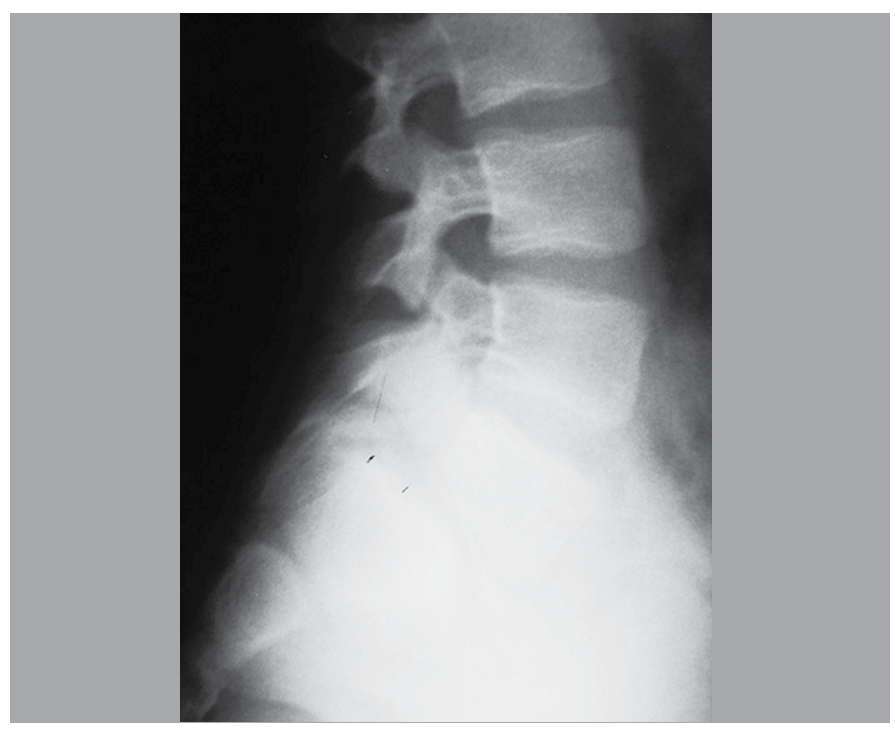

Figure 1. Profile radiography of the case of spondylolysis in L5.

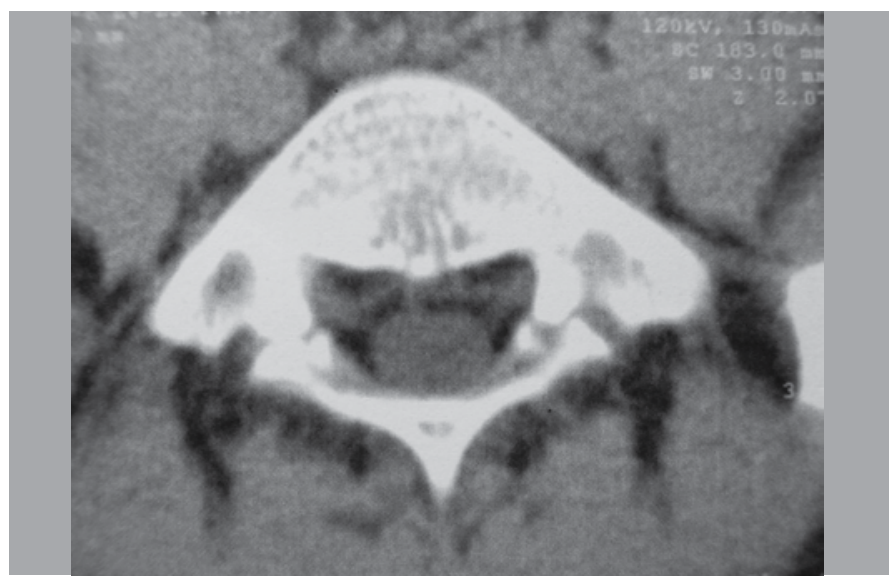

Figure 2. Axial section of a tomography with evidence of bilateral spondylolysis.

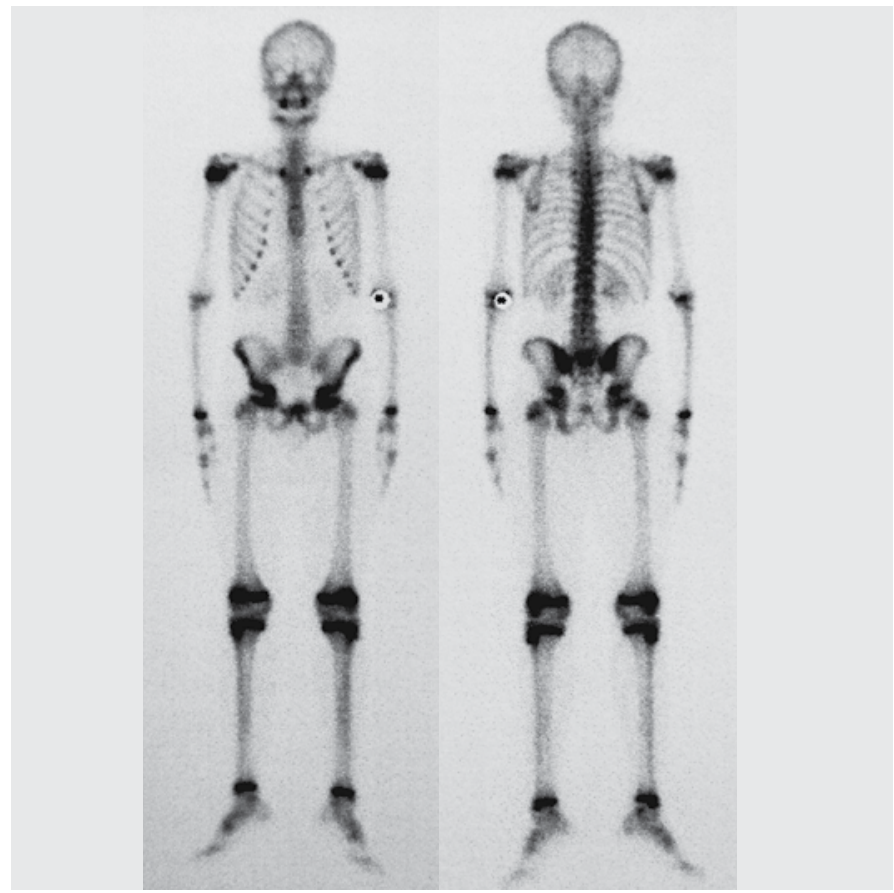

Figure 3. Bone scintigraphy, a sensitive test, though not very specific. 


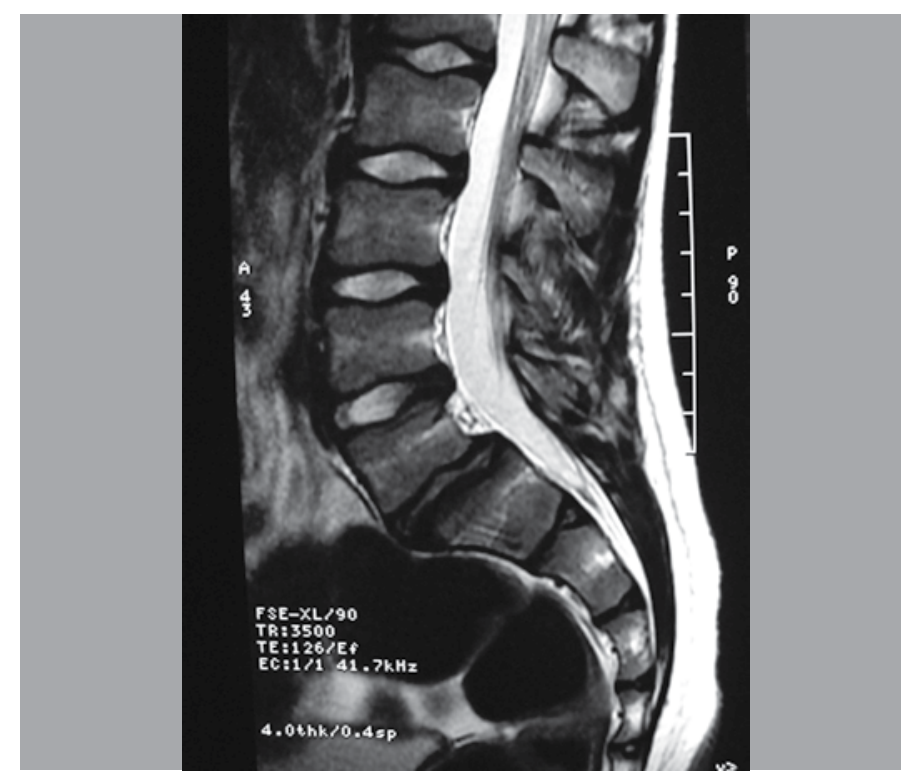

Figure 4. The use of magnetic resonance imaging has not yet been established in these cases.

In Brazil, Carazzato ${ }^{18}$ found that $12 \%$ of the young athletes had spinal injuries resulting from long-term exposure, and Pedrinelli19, in a specific study involving soccer players, observed that around $4 \%$ of all injuries are located in the spine. But both studies included the cervical, thoracic, and lumbar segments and considered both macro- and micro-traumas in the statistics.

In our study, only one patient complained of low back pain, an incidence that is in agreement with Pedrinelli's ${ }^{19}$ findings of a low incidence of spinal injury among soccer players. Physical examination revealed a worsening on lumbosacral hyperextension and on palpation of the posterior elements of L5, clinical characteristics more common to spondylolysis. In the radiographic exam, grade I isthmic spondylolisthesis in the lumbosacral transition was observed, apparently caused by lysis of the pars of $L 5$, a fact confirmed later by CT and MRI. Scintigraphy, an extremely sensitive but not very specific test, ${ }^{20}$ particularly in acute cases, was also performed, but did not pick up signs of inflammatory activity in the region, probably due to the duration of the complaint (about a year). SPECT was not performed on the patient (it was not available), but the literature indicates that it is the best diagnostic method. ${ }^{21,22}$ Only simple front and profile radiographies were performed for all the other athletes, as they had no complaints of low back pain.

Despite the classic indication of oblique views for the detection of spondylolysis, Amato and colleagues confirmed, in a series of 1500 cases, that profile radiography is more sensitive, mainly due to the technical difficulty of performing an oblique view and the large number of false positives. ${ }^{9}$ Saiffudin et $\mathrm{al}^{23}$, using tomographic studies, reported that most of the injuries were very close to the coronal plane, which would explain the greater accuracy of profile, as opposed to oblique, radiography views. Our intention to minimize the radiation to which each athlete evaluated was exposed contributed to our decision to perform only front and profile views.

Full body bone scintigraphy is an extremely sensitive exam as compared to simple radiography, with a relatively low cost, but it is not very specific, and is less accurate than SPECT. ${ }^{20}$ Perhaps it is best used in monitoring the evolution of the injury. ${ }^{20,24}$

CT is a suitable method for study of the complex three-dimensional vertebral anatomy. Studies indicate that it is slightly less sensitive than scintigraphy, probably because it does not identify the inflammatory injuries identified early through scintigraphy, that have not yet developed solution of bone continuity, i.e. Iysis per se.25,26 Its disadvantage is the level of radiation necessary to perform the test. ${ }^{26}$

The value of MRI for the diagnosis of spondylolysis has still not been established, but its capacity for evaluating associated inju- ries, such as degenerative disc disease and muscular-ligamentary distensions, and most importantly, for identifying differential diagnoses of similar symptoms, such as osteoid osteoma and infection, justify its use. ${ }^{22,25,27}$ There are considerable advantages to not using ionized contrast or radiation, especially in young females. ${ }^{25}$ Additionally, it is likely that MRI is capable of identifying injuries earlier than $\mathrm{CT}^{28,29}$

SPECT appears to be the most accurate method, to the point of significantly increasing the incidence of edema in pars articularis in symptomatic athletes, which would correspond to the initial phase of spondylolysis, and enables a clear indication of the degree of activity of the inflammatory process in the region. ${ }^{30}$ The biggest apparent advantage is correlating the positivity of the exam with the presence of the corresponding symptomology ${ }^{22}$, and for this reason, it can be considered the gold standard for detecting spondylolysis in athletes. The difficulty of access to this exam in our country is a challenge to be overcome, but it will certainly facilitate the approach to and management of young symptomatic athletes without positivity for spondylolysis indicated by the other diagnostic methods.

There are no cases of spondylolysis reported in non-ambulatory patients, which reinforces the theory of etiology due to overload. ${ }^{6,31}$ Cases of lysis of the unilateral pars can lead to the same injury in the contralateral pedicle. ${ }^{32,33}$ Capener (1931) apud Goldstein et $\mathrm{al}^{14}$ described the theory of "bonypincers", in which the structures of the posterior elements of L4 and S1 collide with the pars of $L 5$ during hyperextension, causing the fracture. This makes sense when we observe the greater incidence of the disease in athletes who perform these movements exhaustively, as in ballet and artistic gymnastics.

Treatment of this injury is preferably conservative, with the use of a lumbar corset for a short period, qualitative and quantitative reduction in physical activity, and physical therapy for the segmental stabilization of both the surface and deep musculatures. 5,6,11 Most of the cases respond well clinically, even without radiographic changes, when compared to the initial condition. Refractory cases make up $5 \%$ of the total number of symptomatic patients ${ }^{10}$ and surgery is indicated. Direct repair of the injury without arthrodesis and with simple blood irrigation of the focus and external immobilization, or compression with hooks and screws, is the preferred treatment, but cases with spondylolisthesis and significant instability make segmental arthrodesis necessary. ${ }^{11,34-36}$ The safe and correct interpretation of the imaging exams is fundamental to a decision on the best type of treatment.

Physical therapy was very successful in our only symptomatic case, but we did not observe radiographic changes in any of the repeated imaging exams, even at six months following the end of treatment, when the athlete was asymptomatic and playing normally. SPECT was not performed, but it is likely that there would have been differences between exams performed prior to the beginning of treatment, when the patient was in pain, and after his return to training, when he was asymptomatic. In agreement with the literature ${ }^{17}$, his subsequent periodical radiographies showed no progression of the slippage.

From the evidence, we can infer the following about the diagnosis and follow-up of spondylolysis in young athletes: oblique radiography is no more accurate than profile radiography; simple radiographies are not sufficient to clearly identify spondylolysis; scintigraphy has a sensitivity similar to that of CT and MRI, but it is not very specific and does not offer detailed information about the local anatomy; there is controversy over the preference for CT versus MRI because the former localizes and dimensions the affected area more precisely, while the latter identifies the injury earlier, without accurately distinguishing the extent of the bone defect or even the local inflammatory process, but it has the attraction that it does not emit radiation; SPECT can radically change the concepts, and its diagnostic power can even significantly increase the incidence and prevalence of spondylolysis.

Low back pain in young athletes is caused by spondylolysis until it can be proven otherwise, ${ }^{37-39}$ explained by a stress fracture 
associated with the congenital weakness of the pars. The main risk group for its development is young male participants in sports. ${ }^{5,6} \mathrm{Ho}$ wever, in using only simple radiographies, we probably will not find the real incidence of spondylolysis in athletes, whether symptomatic or not. ${ }^{40,41}$ SPECT appears to be essential for the early diagnosis of these injuries. ${ }^{42}$

More studies are needed to define a protocol for the diagnosis and follow-up of young athletes with acute or chronic low back pain, to investigate whether undiagnosed stress injuries might be the most likely cause, given that the etiologies of a large proportion of these cases are not totally clear.

\section{CONCLUSION}

In our sample, soccer was shown to be a very safe sport in terms of the risk of developing chronic injuries of the lumbosacral spine. However, in this study, the real incidence of spondylolysis in these athletes was not determined, because only simple radiographies were used.

All authors declare no potential conflict of interest concerning this article.

\section{REFERENCES}

1. Hutchinson MR. Low back pain in elite rhythmic gymnasts. Med Sci Sports Exerc.1999; 31(11):1686-8.

2. Tall RL, DeVault W. Spinal injury in sport: epidemiologic considerations. Clin Sports Med 1993;12 (3):441-8.

3. Stinson JT. Spine problems in the athlete. Maryland Med J. 1996;45(8):655-8.

4. Lundin O, Hellström M, Nilsson I, Swärd L. Back pain and radiological changes in the thoraco-lumbar spine of athletes. A long-term follow-up. Scand J Med Sci Sports. 2001:11(2):103-9.

5. Bono C. Low back pain in athletes. J Bone Joint Surg Am. 2004;86(2):382-96

6. Leone A, Cianfoni A, Cerase A, Magarelli N, Bonomo L. Lumbar spondylolysis: a review. Skeletal Radiol, 2011:40(6):683-700.

7. Syrmou E, Tsitsopoulos PP, Marinopoulos D, Tsonidis C, Anagnostopoulos I, Tsitsopoulos PD. Spondylolysis: a review and reappraisal. Hippokratia 2010;14(1):17-21.

8. Standaert CJ, Herring SA. Spondylolysis: a critical review. $\mathrm{Br} J$ Sports Med. 2000;34(6):415-22

9. Amato M, Totty W, Gilula L. Espondylolisis of the Lumbar Spine: Demonstration of defects and laminal fragmentation. Radiology, 1984;153(3):627-9.

10. Zukotynski K, Curtis C, Grant F, Micheli L, Treves T. The value of SPECT in the detection of stress injury to the pars interarticularis in patients with low back pain. J Orthop Surg Res. 2010;5:13.

11. Ulibarri J, Anderson P, Escarcega T, Mann D, Noonan K. Biomechanical and Clinical Evaluation of a Novel Technique for Surgical Repair of Spondylolysis in Adolescents. Spine (Phila Pa 1976). 2006;31(18):2067-72.

12. Rajnics P, Templier A, Skalli W, Lavaste F, Illés T. The Association of Sagittal Spinal and Pelvic Parameters in Asymptomatic Persons and Patients with Isthmic Spondylolisthesis. J Spinal Dis Tech. 2010;15(1):24-30

13. Vialle R, Ilharreborde B, Danzac C, Lenoir T, Rillardon L, Guigui P. Is there a sagittal imbalance of the spine in isthmic spondylolisthesis? A correlation study. Eur Spine J. 2007;16(10):1641-9.

14. Goldstein JD, Berger PE, Windler GE, Jackson DW. Spine injuries in gymnasts and swimmers. An epidemiologic investigation. Am J Sports Med. 1980;19(5):463-7.

15. Basile Júnior R, Barros Filho TEP, Oliveira RP, Von Uhlendorff EF, Amatuzzi MM. Lesão da coluna vertebral nos esportes. Rev Bras Ortop 1999;34(2)90-6.

16. Wiltse LL, Newman PH, Macnab I. Classification of spondylolysis and spondylolisthesis. Clin Orthop Rel Res. 1976;(117):23-9.

17. Rossi F. Spondylolysis, spondylolisthesis and sports. J Sports Med Phys Fitness. 1978;18(4):317-40.

18. Carazzato JC. Incidência de lesões traumáticas em atletas competitivos de dez tipos de modalidades esportivas. Rev Bras Ortop. 1992;27:745-58.

19. Pedrinelli, A. Incidência de lesões traumáticas em atletas de futebol [dissertação]. São Paulo: Faculdade de Medicina, Universidade de São Paulo; 1994

20. Elliott S, Hutson MA, Wastie ML. Bone scintigraphy in the assessment of spondylolysis in patients attending a sports injury clinic. Clin Radiol. 1988;39(3):269-72.

21. Bodner RJ, Heyman S, Drummond DS, Gregg JR. The use of single photon emission computed tomography (SPECT) in the diagnosis of low back pain in young patients. Spine (Phila Pa 1976). 1988;13(10):1155-60.

22. Bellah RD, Summerville DA, Treves ST, Micheli LJ. Low back pain in adolescent athletes: Detection of stress injury to the pars interarticularis with SPECT. Radiology 1991;180(2):509-12

23. Saifuddin A, White J, Tucker S, Taylor BA. Orientation of lumbar pars defects; implications for radiographic demonstration and surgical management. J Bone Joint Surg Br.1998;80(2):208-11.

24. Jackson DW, Wiltse LL, Dingeman RD, Hayes M. Stress reactions involving the pars interarticularis in young athletes. Am J Sports Med. 1981;9(5):304-12.

25. Harvey CJ, Richenberg JL, Saifuddin A, Wolman RL. Pictorial review: The radiological investigation of lumbar spondylolysis. Clin Radiol. 1998;53(10):723-8.

26. Congeni J, McCulloch J, Swanson K. Lumbar spondylolysis: a study of natural progression in athletes. Am J Sports Med. 1997;25(2):248-53.

27. Campbell RSD, Grainger AJ. Optimization of MRI pulse sequences to visualize the normal pars interarticularis. Clin Radiol.1999;54(1):63-8.

28. Udeshi UL, Reeves D. Routine thin slice MRI effectively demonstrates the lumbar pars interarticularis. Clin Radiol. 1999;54(9):615-9.

29. Yamane T, Yoshida T, Mimatsu K. Early diagnosis of lumbar spondylolysis by MRI. J Bone Joint Surg Br. 1993;75(5):764-8.

30. Gregory PL, Batt ME, Kerslake RW. Comparing spondylolysis in cricketers and soccer players. Br J Sports Med. 2004;38(6):737-42.

31. Wiltse LL. Etiology of spondylolisthesis. Clin Orthop Relat Res.1957;10:48-60.

32. Garber JE, Wright AM. Unilateral spondylolysis and contralateral pedicle fracture. Spine (Phila Pa 1976). 1986;11(1):63-6.

33. Amari R, Sakai T, Katoh T, Sairyo K, Higashino K, Tachibana K, Yasui N. Fresh stress fractures of lumbar pedicles in an adolescent male ballet dancer: Case report andl iterature review. Arch Orthop Trauma Surg. 2009;129(3):397-401.

34. Gillet P, Petit M. Direct repair of spondylolysis without spondylolisthesis, using a rod-screw construct and bone grafting of the pars defect. Spine (Phila Pa 1976). 1999;24(12):1252-6.

35. Noglle J, Sciubba D, Sandmani, Anderson G, Betz R, Asghar J. Minimally invasive direct repair of lumbar spondylolysis with a pedicle screw and hook construct. Neurosurg Focus. 2008;25(2):E15.

36. Aebi M. Direct screw fixation of the spondylolysis without fusion. Eur Spine J. 2010;19(10):1803-5.

37. Watkins RG. The spine in sports. St. Louis: Mosby-Year Book Inc; 1996

38. Milanese S, Grimer-Somers K. What is adolescent low back pain? Current definitions used to define the adolescent with low back pain. J Pain Res 2010:3 57-66.

39. Amari R, Sakai T, Katoh T, Sairyo K, Higashino K, Tachibana K, Yasui N. Fresh stress fractures of lumbar pedicles in an adolescent male ballet dancer: Case report and literature review. ArchOrthop Trauma Surg. 2009;129(3):397-401.

40. Lisbon E, Bloom R, Dinari G, Robin G. Oblique lumbar spine radiographs: importance in young patients. Radiology. 1984;151(1):89-90.

41. Mohriak R, Silva P, Martins D, Wajchenberg M, Cohen M, Puertas EB. Espondilólise e espondilolistese em ginastas jovens. Rev Bras Ortop. 2010;45(1)79-83.

42. Takemitsu M, Rassi G, Woratanarat P, Shah S. Low Back Pain in Pediatric Athletes With Unilateral Tracer Uptake at the Pars Interarticularis on Single Photon Emission Computed Tomography. Spine (Phila Pa 1976). 2006;31(8):909-14. 